\title{
Forensic Science for Cambodian Justice
}

\section{Melanie Klinkner}

\begin{abstract}
${ }^{1}$
Cambodia is universally associated with its killing fields - a horrific inheritance from the Khmer Rouge era. Whilst mass grave evidence from that era is referred to in history and social science publications on Cambodia, it has not featured in a legal context to date. The establishment of the Extraordinary Chambers in the Courts of Cambodia (ECCC) creates an opportunity for a review of this evidence 30 years after the events. Those alleged to be accountable for Cambodia's killing fields are finally being brought to justice. The question is whether this will occur with or without forensic science evidence from the mass graves.

This article explores the reasons for using forensic science in the Cambodian context and outlines its potential for legal proceedings. Drawing on relevant literature in the forensic and legal areas, the article provides a brief outline of the legal context created by the ECCC and examines various projects that have recorded evidence relating to the mass graves. Employing an analysis of semi-structured, in-depth interviews with forensic and legal experts as well as representatives from the ECCC and the Documentation Center of Cambodia (DC-Cam), the article explores the value of forensic science for the ECCC, including its impact on humanitarian aspects in Cambodia.
\end{abstract}

\section{Introduction}

Cambodia is universally associated with its killing fields - a horrific inheritance from the Khmer Rouge era. The killing fields and memorials displaying the bones of victims are a constant reminder of this period that serve both a historical and an educational function. Whilst mass grave evidence from the Khmer Rouge era is referred to in history and social science publications on Cambodia, it has not been used in a legal context, not even in the 1979 in absentia trial of Pol Pot and leng Sary. ${ }^{2}$ The establishment of the Extraordinary Chambers in the Courts of Cambodia (ECCC) creates an opportunity for a review of this evidence 30 years after the events. Those alleged to be accountable for

\footnotetext{
*PhD candidate, Centre for Legal Studies, Bournemouth University, UK. E-mail: mklinkner@bournemouth.ac.uk

${ }^{1}$ The author wishes to thank all the interviewees for sharing their experiences and views, as well as Bournemouth University and the Harold Hyam Wingate Foundation for financially supporting this project and Professors Nick Grief and Margaret Cox for their continuous guidance and encouragement.

${ }^{2}$ Howard J. De Nike, John Quigley and Kenneth J. Robinson, ed., Genocide in Cambodia: Documents from the Trial of Pol Pot and leng Sary (Philadelphia: University of Pennsylvania Press, 2000).
} 
Cambodia's killing fields are finally being brought to justice. The question is: with or without forensic science evidence from the mass graves?

Scholars believe that Cambodia's mass graves and human remains will provide valuable physical evidence for any legal proceedings and be of probative value. ${ }^{3}$ Despite the lapse of time and the process of decay, the bones still contain information. With the help of forensic science, 'the violent method of death can be determined in a large number of cases, ${ }^{4}$ and the time of death, sex, age and stature of the victim can be established. It is unclear if the mass graves will be examined from a forensic science perspective or whether the ECCC will be content with witness testimonies and documentary evidence, including existing social science research into the number of graves and the death toll. This article explores the reasons for using forensic science specifically the disciplines of forensic archaeology, forensic anthropology and forensic pathology - in the Cambodian context and outlines its potential for legal proceedings. In general, forensic scientists:

- Examine and interpret material to provide relevant, previously unknown information;

- Collate the results in a report for the prosecution, or the defence, and for presentation in court; and

- Present verbal evidence as expert witnesses during trials. ${ }^{5}$

\footnotetext{
${ }^{3}$ See, Mohamed Ali Lejmi, 'Prosecuting Cambodian Genocide: Problems Caused by the Passage of Time since the Alleged Commission of Crimes,' Journal of International Criminal Justice 4 (2006): 300-306; Kelly Dawn Askin, 'The Investigation and Prosecution,' Justice Initiatives (Spring 2006): 72-84.

${ }^{4}$ United Nations, 'Report of the Group of Experts Established Pursuant to General Assembly Resolution 52/135 Human Rights Questions, including Alternative Approaches for Improving the Effective Enjoyment of Human Rights and Fundamental Freedoms' (New York: United Nations, 1999), para. 52.

${ }^{5}$ See, Peter Cobb, 'Forensic Science,' in Crime Scene to Court: The Essentials of Forensic Science, ed. Peter White (Cambridge: The Royal Society of Chemistry, 1998).
} 
In the forensic science exhumations conducted by the International Criminal Tribunal for the former Yugoslavia (ICTY), for example, the investigation objectives for the Srebrenica exhumations were more specifically to:

- Corroborate victim and witness accounts of the massacres;

- Determine an accurate count of victims;

- Determine cause and time of death;

- Determine the sex of victims;

- Determine the identity of victims (a process that is ongoing with the help of DNA analysis); and

- Identify links to the perpetrators. ${ }^{6}$

Whilst these objectives are dependent on the investigative strategy and context of purported crimes, they demonstrate the potential of forensic science excavations.

Drawing on relevant literature in the forensic and legal fields, this article gives a brief outline of the legal context created by the ECCC before looking at various projects that have recorded evidence relating to the mass graves in Cambodia. Analysis of semistructured, in-depth interviews with forensic and legal experts as well as representatives from the ECCC and the Documentation Center of Cambodia (DC-Cam) ${ }^{7}$ informs the

\footnotetext{
${ }^{6}$ See, Witness Statement by Investigations Team Leader Dean Paul Manning, Milošević (IT-02-54-T), 24 November 2003, § 4, http://www.domovina.net/archive/2003/20031124_manning.pdf. Whilst ICTY investigations contributed to identifying mass grave victims, organisations such as Physicians for Human Rights (PHR) and later the International Commission on Missing Persons (ICMP) were responsible for the positive identification of victims from Bosnia and Herzegovina. In order to successfully prosecute crimes such as genocide and crimes against humanity, personal identification of individuals is not necessary, but information regarding age, ancestry, sex, trauma and artifacts is.

${ }^{7}$ DC-Cam was founded by Yale University's Cambodian Genocide Project as a field office in Phnom Penh. In 1997, DC-Cam became an independent, nongovernmental and not-for-profit research institute committed to researching and documenting the Khmer Rouge era.
} 
paper and aids in the exploration of the potential of forensic science for the ECCC and for Cambodian society in general. ${ }^{8}$

\section{Historical and Legal Context}

Between 17 April 1975 and 7 January 1979, the Pol Pot regime, in its desire to create an agrarian, Marxism-inspired utopia, is believed to have caused the deaths of between 740,000 and $3,314,000$ people through execution, torture, overwork, starvation and disease. ${ }^{9}$ The debate about 'the numbers' is ongoing. The director of the Genocide Studies Program at Yale University, Ben Kiernan, relying upon demographic data and a comparison of pre-1975 and post-1979 population figures, believes that the death toll is 'between 1.671 and 1.871 million people, 21 to 24 percent of Cambodia's 1975 population, ${ }^{10}$ whilst Bruce Sharp argues that it is around 2.18 million. ${ }^{11}$ The Cambodian people, rightly or wrongly, refer to the atrocities committed during the period of Democratic Kampuchea as genocide, ${ }^{12}$ and they are awaiting justice to this day.

\footnotetext{
${ }^{8}$ To guarantee the anonymity of research participants, quotations that illustrate the interviewees' views will remain unattributed.

${ }^{9}$ Tom Fawthrop and Helen Jarvis, Getting Away with Genocide? Elusive Justice and the Khmer Rouge Tribunal (London: Pluto Press, 2004).

${ }^{10}$ Ben Kiernan, 'The Demography of Genocide in Southeast Asia: The Death Tolls in Cambodia, 1975-79, and East Timor, 1975-80,' Critical Asian Studies 35(4) (2003): 587.

${ }^{11}$ Bruce Sharp, 'Counting Hell,' Mekong Net, 2005, http://www.mekong.net/cambodia/deaths.htm. Sharp reviews the death toll proposed by Michael Vickery from census data $(740,800)$; by Ben Kiernan from surveys (1.671 million to 1.871 million); by Craig Etcheson, whose estimations are based on the DC-Cam mapping project and house-to-house surveys ( 3 million); and by Patrick Heuveline, who analysed demographic trends ( 2 million) to come up with his own estimate of 2.18 million.

12 The notorious Tuol Sleng Prison, where many victims were photographed before being killed, is now a 'genocide museum.' Choeung Ek is referred to as a 'genocide memorial.' In an in absentia trial in 1979, Pol Pot and leng Sary were charged with the crime of genocide (Nike, Quigley and Robinson, supra $n$ 2), but the definition of genocide used at that time encompassed groups of innocent people as part of protected groups. See, Scott Luftglass, 'Crossroads in Cambodia: The United Nations' Responsibility to Withdraw Involvement from the Establishment of a Cambodian Tribunal to Prosecute the Khmer Rouge,' Virginia Law Review 90 (2004): 893-964. A disagreement has emerged between scholars as to whether the atrocities committed in Cambodia qualify as genocide or 'autogenocide,' given that 'political genocide' is a blind spot in the 1948 Genocide Convention. See, Jörg Mezel, 'Justice Delayed or Too Late for Justice? The Khmer Rouge Tribunal and the Cambodian "Genocide," 1975-79,' Journal of Genocide Research 9(2) (2007): 215-233; Patricia M. Wald, 'Prosecuting Genocide,' Justice Initiatives (Spring 2006): 85-96.
} 
To many scholars, the international community unquestionably shares guilt in the atrocities committed by the Khmer Rouge because of its inaction. ${ }^{13}$ The realpolitik practised by the international community in the 1980s, by which the Khmer Rouge received funding from China and aid from the US via its allies and was permitted to keep Cambodia's United Nations (UN) seat, contributed to the delay in justice and allowed the Khmer Rouge to engage in guerrilla warfare. ${ }^{14}$ Some argue that it was precisely western governments' support which helped Pol Pot and other senior regime leaders escape prosecution from 1979, when Vietnamese troops and Cambodian anti-Khmer Rouge soldiers overthrew the Pol Pot regime, until 1997, when remnants of the Khmer Rouge held a kangaroo court trial of Pol Pot in which he was convicted of committing crimes against other Khmer Rouge leaders, with no mention of any crimes against the Cambodian people. ${ }^{15}$ During a period when the international community was working toward ending the 'culture of impunity,' Pol Pot, 'whose name had come to symbolize impunity for unconscionable crimes, ${ }^{16}$ died on 15 April 1998.

In 1997, the Cambodian government requested the UN's assistance in bringing senior Khmer Rouge leaders to justice. ${ }^{17}$ The Group of Experts for Cambodia, established pursuant to UN General Assembly Resolution 52/135, confirmed that evidence suggested patterns of abuse, including forced population movement, forced labour and inhumane living conditions, attacks on enemies of the revolution (officials of

\footnotetext{
${ }^{13}$ Luftglass, supra $\mathrm{n} 12$. The US is believed to have played a significant role in the Khmer Rouge's rise to power by destabilizing Cambodia both economically and militarily through its B-52 carpet-bombing of the Cambodian countryside in 1969-1973. Aaron J. Buckley, 'The Conflict in Cambodia and Post-Conflict Justice,' in Post-Conflict Justice, ed. M. Cherif Bassiouni (Ardsley: Transnational Publishers, 2002).

${ }^{14}$ Fawthrop and Jarvis, supra $\mathrm{n} 9$.

15 lbid.

16 Buckley, supra $\mathrm{n} 13$ at 644.

17 See, for example, Craig Etcheson, 'A "Fair and Public Trial”: A Political History of the Extraordinary Chambers,' Justice Initiatives (Spring 2006): 7-23.
} 
previous regimes, ethnic minorities, the intelligentsia, religious leaders and institutions)

and purges within the Communist Party. ${ }^{18}$

Because of a lack of qualified legal professionals, the necessary legal

infrastructure and 'a culture of respect for an impartial criminal justice system' ${ }^{19}$ in

Cambodia, the UN panel of experts advised against trials being held within the country. ${ }^{20}$

After often troublesome and interrupted negotiations ${ }^{21}$ between the $\mathrm{UN}$ and the Kingdom

of Cambodia, the end result diverged significantly from the Group of Experts'

recommendations. Taking into consideration the lessons learned from the ad hoc

tribunals for the former Yugoslavia and Rwanda (high costs, bureaucracy, remoteness

and slow proceedings) and the demands of the Cambodian government, the UN

eventually agreed on a 'mixed' tribunal, situated in Phnom Penh, to try senior Khmer

Rouge officials. In May 2003, seven years after the initial request for assistance, the

General Assembly adopted Resolution 57/228B approving the Draft Agreement between

the Royal Government of Cambodia and the UN. ${ }^{22}$ On 6 June 2003, Sok An, Senior

Minister in Charge of the Council of Ministers, and Hans Corell, then-UN Under-

Secretary-General for Legal Affairs, signed an agreement to try

\footnotetext{
${ }^{18}$ United Nations, supra n 4.

19 lbid., para. 129.

20 This concern remains valid. According to the 2007 Global Corruption Report, corruption levels in the judiciary of Cambodia are still high, with judicial officers being amongst the least trusted government staff: 'Chronic underfunding for judges and courts, coupled with a culture that places a high value on giving gifts to people in authority, contributes to a high level of petty corruption in Cambodia's courts.' Samantha Ford and Theary C. Seng, 'Corruption in the Judiciary of Cambodia,' in Global Corruption Report, ed. Diana Rodriguez and Linda Ehrichs (Transparency International, 2007), 183. This situation, according to Antonia Potter, has partially been caused by assistance opportunities being wasted: 'Because assistance actors had identified that state institutions were weak and corrupt, and because some of them had only limited funds, they chose not to work with the state institutions, pouring their resources instead into what was then a very nascent Khmer civil society. The result, unsurprisingly, is that access to justice and respect for human rights in Cambodia is considered today to be unacceptably poor, despite more than a decade of donor engagement.' Antonia Potter, The Rule of Law as the Measure of Peace? Responsive Policy for Reconstructing Justice and the Rule of Law in Post-Conflict and Transitional Environment (Geneva: Centre for Humanitarian Dialogue, 2004), 10.

${ }^{21}$ For a detailed description of the negotiations between Cambodia and the UN, see, Etcheson, supra $\mathrm{n}$ 17; Kelly Whitley, 'History of the Khmer Rouge Tribunal: Origins, Negotiations, and Establishment,' in The Khmer Rouge Tribunal, ed. John D. Ciorciari (Phnom Penh: Documentation Center of Cambodia, 2006); Fawthrop and Jarvis, supra n 9; Luftglass, supra n 12.

22 Documentation Center of Cambodia, 'Chronology of the Khmer Rouge Tribunal,' http://www.dccam.org/Archives/Chronology/Chronology.htm.
} 
senior leaders of Democratic Kampuchea and those who were most responsible for the crimes and serious violations of Cambodian penal law, international humanitarian law and customs, and international conventions recognized by Cambodia, that were committed during the period from 17 April 1975 to 6 January $1979 .^{23}$

The ECCC is to try former leaders for the following crimes under domestic and international law: genocide; war crimes; crimes against humanity; torture; religious persecution; homicide; destruction of cultural property; and offences against diplomatically protected persons. ${ }^{24}$

The ECCC, as the name indicates, is part of the Cambodian courts but includes international participation. It is a unique hybrid court that has Cambodian law as its foundation but incorporates international law standards. Its chambers and judiciary offices (Pre-trial Chamber, Trial Chamber, Supreme Court Chamber, Office of the Coprosecutors and Office of the Co-investigating Judges) are made up of Cambodian and international staff. Both the Trial Chamber (composed of three Cambodian and two international judges) and the Supreme Court Chamber (composed of four Cambodian and three international judges) require a supermajority verdict. At the Trial Chamber level, an affirmative vote of at least four judges is needed, and in the Supreme Court Chamber, an affirmative vote of at least five judges is required. ${ }^{25}$

\footnotetext{
${ }^{23}$ The Royal Government of Cambodia and the United Nations, Agreement between the United Nations and the Royal Government of Cambodia Concerning the Prosecution under Cambodian Law of Crimes Committed During the Period of Democratic Kampuchea (Phnom Penh: The Royal Government of Cambodia, 2003), 1.

${ }^{24}$ Secretariat of the Royal Government Task Force, Office of the Council or Ministers, Kingdom of Cambodia, 'An Introduction to the Khmer Rouge Trials,' Secretariat of the Task Force for the Khmer Rouge Trials (2006), http://www.cambodia.gov.kh/krt/english/introduction_eng/Khmer\%20Rouge\%20Trials_English.pdf; Aubrey Ardema, 'The Crimes to Be Judged by the Extraordinary Chambers,' in The Khmer Rouge Tribunal, ed. John D. Ciorciari (Phnom Penh: Documentation Center of Cambodia, 2006).

${ }^{25}$ How this supermajority system will work in practice remains to be seen. Buckley believes it to be a 'recipe for disaster.' He predicts, 'the three Cambodian judges will dance loyally to the tune of Hun Sen, and the two UN-appointed judges will refuse to join the charade. Gridlock is inevitable. The Cambodian public will be an exasperated spectator to the jerky, redundant movements of a justice system crippled by political compromise.' Buckley, supra $\mathrm{n} 1$ at 650 . It is ironic that mixed tribunals, such as those for East Timor, Sierra Leone and Kosovo, followed the idea of a 'Cambodian model' before its realisation. Because hybrid courts are visible to the local population, employ local judges and staff, encourage local ownership, help build capacity locally and come at a far lesser cost, in recent years they have been favoured over purely
} 
International and Cambodian judges and prosecutors were appointed on 7 May $2006 .{ }^{26}$ On 18 July 2007 , the co-prosecutors filed an introductory submission requesting that the co-investigating judges investigate the identified crimes and charge those deemed responsible. Preliminary investigations identified five suspects. In order to support their submission, the co-prosecutors

transmitted more than 1,000 documents...including third party statements and/or written records of over 350 witnesses, a list of 40 other potential witnesses, thousands of pages of Democratic Kampuchea-era documentation and the location of over 40 [sic] undisturbed mass graves. $^{27}$

All five suspects, Kaing Guek Eav (also known as Duch), Nuon Chea (known as Brother Number Two), leng Sary (Deputy Prime Minister and Foreign Minister of Democratic Kampuchea), leng Thirith (Minister of Social Affairs and Head of Democratic Kampuchea's Red Cross Society) and Khieu Samphan (Head of State in Democratic Kampuchea), are currently in detention. As outlined by the co-prosecutors, most of the evidence is expected to come from witness testimony and documents. As one interviewee summarised:

One thing we have here is no shortage of evidence. We have millions of pages of documents. We have millions of witnesses; we have thousands of perpetrators that can be called on to testify. We have 25 years of scholarly analysis to draw on. ${ }^{28}$

Furthermore, the country has an abundance of a particular type of physical evidence: human remains.

international ad hoc tribunals in The Hague. Neil J. Kritz, 'Progress and Humility: The Ongoing Search for Post-Conflict Justice,' in Bassiouni, supra n 13.

${ }^{26}$ Documentation Center of Cambodia, supra $\mathrm{n} 22$.

${ }^{27}$ Extraordinary Chambers in the Courts of Cambodia Office of the Prosecutor, 'Statement of the Co-prosecutors' (Phnom Penh: Extraordinary Chambers in the Courts of Cambodia, 2007), 6(emphasis added).

${ }^{28}$ Personal interview, 23 April 2007, Phnom Penh, Cambodia. 


\section{Exhumations by the Vietnamese}

The Vietnamese are believed to have undertaken forensic excavations in the early and late 1980s, but to date they have made no reports public. DC-Cam researchers can only draw inferences as to the activities of the Vietnamese from the traces excavators left on human remains, from how the remains were arranged by bone type at memorial sites and from photographic records. It is reported that in 1980, about 89 of the estimated 130 mass graves in the area of Choeung Ek, the killing field on the outskirts of Phnom Penh, were excavated by Vietnamese authorities using mostly untrained staff; hence, not all fragments were retained. ${ }^{29}$ The human crania are stored in a stupa at Cheoung Ek, a 62-metre-tall memorial built in 1988. According to Helen Jarvis and Tom Fawthrop, in 1988 and 1989, an expert team from Ho Chi Minh University in Vietnam examined and measured the 8,000 exhumed crania from Choeung Ek during three trips to the field. It became apparent from the interviews conducted for this paper that despite DC-Cam's efforts to obtain them, no reports as to the findings and methods employed seem to be available.

\section{Surveys by the Documentation Center of Cambodia}

DC-Cam aims to locate the various sites containing human remains from the Khmer Rouge era. In DC-Cam's 1999 mapping project analysis, Craig Etcheson describes the center's formidable task of trying to locate and map each mass grave, prison and memorial in Cambodia through global positioning system mapping, as well as through more traditional fieldwork, with investigators exploring Cambodia for killing fields and

\footnotetext{
${ }^{29}$ See, Sabrina C. Ta'ala, Gregory E. Berg and Kathryn Haden, 'Blunt Force Cranial Trauma in the Cambodian Killing Fields,' Journal of Forensic Science 51(5) (2006): 996-1001; Wynne Cougill, 'Buddhist Cremation Traditions for the Dead and the Need to Preserve,' Documentation Center of Cambodia, http://www.dccam.org/Projects/Maps/Buddhist_Cremation_Traditions.htm.
} 
graves. ${ }^{30}$ Ninety-five percent of the graves DC-Cam located had been exhumed by the Cambodian government without staff trained in forensic sciences or disturbed and robbed by locals looking for family members or valuables. The estimated number of bodies at the mapped sites is based on interviews with witnesses, perpetrator testimony, counts of crania at memorial sites, comparisons with records kept from government exhumations and estimates by DC-Cam staff based on apparent grave size and their own experiences from previously assessed graves. They employed no forensic science methods, however, in estimating grave sizes to infer numbers. From 1995, the year the project started, to 2007 , DC-Cam identified 19,733 mass burial pits that were organised in 388 burial sites, providing an idea of the systematic character of the killing and torture. ${ }^{31}$ In the center's 1999 report, Etcheson speculates that 1,110,829 victims of execution are buried in these mass graves.

Without exhumations and analysis of the bodies in the graves, this figure remains unsubstantiated. ${ }^{32}$ Furthermore, as no attempts have been made to determine the size and shape of the excavated and unexcavated graves through archaeological surveys to assess how many bodies they might have contained, the numbers are easily disputed. Indeed, Etcheson acknowledges that because of the methods employed, which were based on social science research and on the interviewing and counting skills of project staff untrained in forensic sciences, the numbers lack scientific certainty. Consequently,

\footnotetext{
${ }^{30}$ Craig Etcheson, 'Mapping Project 1999: The Analysis. "The Number”: Quantifying Crimes against Humanity in Cambodia,' Documentation Center of Cambodia,

http://www.dccam.org/Projects/Maps/Mass_Graves_Study.htm. These mass graves are then divided into subcategories: some denote earthen pits, wells or caves while others relate to people burned in brick hills or bodies scattered on open land.

${ }^{31}$ Documentation Center of Cambodia, 'Mapping Project: 1995-Present,' http://www.dccam.org/Projects/Maps/Mapping.htm (accessed 17 November 2006). The Cambodian Genocide Program has created an interactive map that displays the mass grave sites. The map can be found at http://maps.library.yale.edu/website/cgp/viewer.htm (accessed 8 February 2007).

${ }^{32}$ Kiernan, supra n 10.
} 
he recommends 'a formal, full scale forensic project' ${ }^{33}$ to add credibility to the mapping project and to extract further information from the physical evidence.

\section{Recent Forensic Projects}

A case report published in 2006 presents the findings of a study of 85 crania from the stupa at Choeung Ek. This project was supported by the Joint POW/MIA Accounting Command (JPAC) and the Kingdom of Cambodia. and the report describes a pattern of systematic execution through blows on a specific area on the back of victims' heads that is sensitive due to its proximity to the cerebellum, brainstem and spinal cord. ${ }^{34}$ In addition to perimortem damage, more recent postmortem damage of the crania, such as loss of teeth, was noted. The authors conclude that more killing techniques, such as the use of plastic bags for suffocation, might be detected through carefully conducted forensic examinations of mass graves and human remains. ${ }^{35}$ Further research into methods of killing would yield valuable information for legal actions related to these crimes. Interestingly, none of the interviewees mentioned this study, though they regularly referred to DC-Cam studies and early exhumations by the Vietnamese.

In 2003, DC-Cam launched what it called a forensic project, comprising an exhibition of crania and a site selection study in preparation for a full-scale multidisciplinary forensic exhumation. ${ }^{36}$ The exhibition of crania from Choeung Ek was designed to demonstrate the potential of human remains to serve as valuable evidence of Khmer Rouge crimes and to yield medico-legal information. Forensic experts took samples from the crania that had been excavated in the 1980s and preserved in stupas and examined the crania to determine the age, sex, trauma and cause of death of each

\footnotetext{
${ }^{33}$ Etcheson, supra $\mathrm{n} 30$ at 15.

34 Ta'ala, Berg and Haden, supra n 29.

${ }^{35}$ Ibid.

${ }^{36}$ Documentation Center of Cambodia, Forensic Pathology and Anthropology of Historical Mass Killing in Cambodia (Phnom Penh: Documentation Center of Cambodia, 2004).
} 
victim. The selected crania show blunt-force trauma, sharp-force trauma and gunshot wounds. Explanations of the findings were intended to educate Cambodians about the value of forensic science in terms of recording evidence and proving elements of crimes. DC-Cam staff say they refrained from actually displaying the examined crania in public because of a 'controversy in Cambodian society over whether this is appropriate, ${ }^{37}$ as well as then-King Norodom Sihanouk's dislike of such displays. The crania now are housed in a separate room at Tuol Sleng Museum.

DC-Cam employed forensic experts to conduct a site selection survey in order to identify appropriate sites at which to conduct forensic exhumations. To make the planned study authoritative, the forensic scientists insisted on finding easily accessible, undisturbed graves - a task that proved difficult as witnesses' memories had faded and most graves had been disturbed. After a physical inspection of 53 sites led by Canadian pathologist Michael Pollanen, the team concluded that only six sites were undisturbed and suitable for full-scale forensic exhumations. The sites have been kept confidential by the center to protect them from grave robbers.

DC-Cam aimed to use the evidence gathered through forensic science to complement the evidence it had already obtained through the social science methods of gathering witness statements and estimating the number of dead. Furthermore, the project was designed to test the accuracy of witness statements gathered through the mapping project in order to confirm that the sites contain victims of Khmer Rouge atrocities and to establish how the victims died. However, full-scale exhumations were never started. The decision by DC-Cam to put exhumations on hold was, apart from funding issues, justifiable given the imminence of the tribunal. The quest to document and investigate human rights abuses can, in some circumstances, hinder criminal

\footnotetext{
${ }^{37}$ Documentation Center of Cambodia, 'Forensic Exhibition,' 2004, http://www.dccam.org/Projects/Forensic_Study/Forensics_Exhibition.htm.
} 
investigations. ${ }^{38}$ DC-Cam was careful not to engage in investigations that the ECCC potentially wanted to undertake in order to avoid damaging evidence or rendering it inadmissible in court.

\section{Significance for the ECCC}

In principle, under Cambodia's civil law system, any evidence can be admitted provided it is relevant and has been obtained through lawful methods. Despite the large number of excavated, disturbed and robbed mass graves, few forensic exhumations have been conducted. Insufficient records from the exhumations conducted by the Vietnamese render their work useless to the court. Even if scientifically sound reports exist, the findings could be challenged because of the political situation in which the excavations were conducted and the potential propaganda value of such excavations. The two recent forensic studies of crania from Choeung Ek could encounter similar criticisms, as both reports build on the Vietnamese exhumations and are scientifically limited by their small sample size, selection bias and lack of taphonomic knowledge.$^{39}$ It is thus questionable whether any of the forensic evidence that has been recovered and examined would be given much weight by ECCC judges.

In general, it is debatable whether forensic science investigations conducted outside of a legal process qualify as impartial and independent. Derived from the Latin word forensis - meaning publicly, belonging to the market, to the court - forensic science is employed for legal and social objectives. Forensic scientists' overriding duty is to the court and the administration of justice. According to DC-Cam representatives, the

\footnotetext{
${ }^{38}$ As was experienced in the former Yugoslavia, overly close cooperation with non-governmental organizations (NGOs) can cause problems when human rights investigations by NGOs get in the way of criminal investigations conducted by the tribunal: 'In the former Yugoslavia, this sort of problem caused the relationship between the criminal investigators and the NGOs to deteriorate to the point where the tribunal demanded that human rights groups cease and desist taking statements from witnesses, a prospect disagreeable to NGOs who had spent a great deal of time and energy documenting violations of humanitarian law.' Raymond McGrath, 'Problems of Investigations into War Crimes and Crimes Against Humanity During and After Ethnic Conflict,' in Bassiouni, supra n 13 at 902.

${ }^{39}$ Taphonomy is the study of decaying organisms over time.
} 
center's forensic investigations had the explicit authorisation and backing of the Cambodian government. It received general authorisation from Prime Minister Hun Sen in 2001 and specific authorisation from Deputy Prime Minister and Co-minister of the Interior, Sar Kheng, on 10 March 2003. DC-Cam says that the exhumations were carried out in compliance with legal and regulatory provisions. ${ }^{40}$ Because the work was conducted under the auspices of an NGO and without a legal mandate, however, it could be accused of bias.

As DC-Cam has the largest archive of documents relating to the Khmer Rouge era, it cooperates with the ECCC and provides access to original papers and statements obtained through interviews. DC-Cam explicitly states that its mission is to collect and preserve evidence, including evidence from its mapping and forensic projects, for posterity and legal contexts:

The first [objective] is to record and preserve the history of the Khmer Rouge regime for future generations. The second is to compile and organize information that can serve as potential evidence in a legal accounting for the crimes of the Khmer Rouge. These objectives represent our promotion of memory and justice, both of which are critical foundations for the rule of law and genuine national reconciliation in Cambodia. ${ }^{41}$

DC-Cam has made available more than 400,000 pages of documents, microfilms, scans and photocopies to the co-prosecutors, including the entire mapping project of undisturbed graves.

\section{Forensic Science Exhumations for the ECCC}

The co-investigating judges were keen to explore the question of whether the ECCC needed forensic science investigations. A confidential forensic needs assessment was conducted by Dr. Andrew Thompson, who had been involved in establishing and

\footnotetext{
${ }^{40}$ Documentation Center of Cambodia, supra $\mathrm{n} 37$.

41 Documentation Center of Cambodia, 'History and Description of DC-Cam,' http://www.dccam.org/Abouts/History/Histories.htm.
} 
managing forensic programmes for the international tribunals for Rwanda and the former Yugoslavia. The assessment was submitted to the ECCC co-investigating judges in June $2007 .^{42}$ In accordance with Rule 31 of the ECCC's internal rules, it is the coinvestigating judges who decide whether forensic work is needed to get an approximation of the true course of events. ${ }^{43}$ This decision can be triggered by requests from the co-prosecutors or the defence, but ultimately it is the co-investigating judges, or the Trial Chamber, that initiate any forensic work by nominating experts to conduct specific tasks.

Whether the ECCC ventures into conducting forensic science exhumations depends largely on what the Extraordinary Chambers aim to achieve. The trials need to prove what happened beyond a reasonable doubt through a fair legal process that is beyond reproach. According to some interviewees, provided that the trials are indeed fair and not subject to political pressure, the evidence, conclusions and judgments could produce an authoritative historical narrative. The Cambodian people are still waiting to hear the reasons why the atrocities were committed, and the ECCC would urge the accused to explain both what happened and why it happened. If anything, this means that the ECCC will engage in a historic dispute, ${ }^{44}$ not a medico-legal one. However, the purpose of a trial is first and foremost, as philosopher Hannah Arendt notes,

\footnotetext{
42 In general, the importance of forensic work has been recognised by the ECCC. According to two respondents, training provided for investigative police and ECCC staff 'included sessions on processing crime scenes and documenting evidence collection. The sessions were more of an introductory nature and dealt with basic principles regarding collection of evidence.'

${ }^{43}$ Rule 31 states, 'Expert opinion may be sought by the co-investigating judges or the Chambers, on any subject deemed necessary to their investigations of proceedings before the ECCC.' Extraordinary Chambers in the Courts of Cambodia, Internal Rules (Cambodia: Extraordinary Chambers in the Courts of Cambodia, 2007).

${ }^{44}$ There is indeed a danger that the Extraordinary Chambers may lose sight of the individuals on trial and focus on the historical and political context at the time, thus becoming 'a history lesson' debating the 'plausibility of the historical "interpretations."' Martti Koskenniemi, 'Between Impunity and Show Trials,' in Max Planck Yearbook of United Nations Law, ed. Jochen A Frowein and Rüdiger Wolfrum (Leiden: Martinus Nijhoff Publishers, 2002), 17. However, as Wald notes, judges tend not to be 'competent historians' and she cautions that 'unless the history has some direct relationship to the intent or knowledge of the accused in the context in which he or she committed the alleged crime or to an element of the crime itself...the court should forget the history or merits of the conflict, and concentrate on the specific act...that is charged.' Wald, supra n 12 at 86-87.
} 
to render justice, and nothing else; even the noblest of ulterior purposes...can only detract from the law's main business: to weigh the charges brought against the accused, to render judgment, and to mete out due punishment. ${ }^{45}$

Thus, in order to render justice, the co-investigating judges must select the most suitable evidence relevant to the charges.

\section{Why It Happened}

A number of questions, as one participant explained, remain unanswered: 'Why did it happen? Why did we have to suffer this much? Why did our children destroy this country? What were they thinking?'46 Although the ECCC's primary objective is not to answer existential questions of this nature, it will inevitably touch upon why the crimes were committed. 'If we explain these crimes,' continued the interviewee, 'they will go part of the way towards answering those questions. And that is what many, many people really want.'

One common explanation for what happened during Democratic Kampuchea is that its political leaders were obsessed with ideology - an ideology whose overall goal legitimised the most perverse means to achieve it. According to one scholar's opinion

[t]he Khmer Rouge leadership most likely did not want to destroy the nation but 'only' had the plan to fundamentally change it. Khmer were not killed because they were Khmer but because they were thought to be political or social enemies. ${ }^{47}$

None of the Khmer Rouge leaders has formally had to justify her or his actions before a court, or the people for that matter, and take responsibility. Furthermore, the knowledge obtained through social science research and its interpretations, mostly conducted by non-Cambodians in the English language, is not necessarily accessible to

\footnotetext{
45 Hannah Arendt, Eichmann in Jerusalem: A Report on the Banality of Evil (London: Penguin, 1994$), 253$.

${ }^{46}$ Personal interview, 23 April 2007, Phnom Penh, Cambodia.

${ }^{47}$ Mezel, supra n 12 at 222.
} 
Cambodians. ${ }^{48}$ Whilst forensic science is unlikely to help us understand why things happened, it will be able to clarify what happened and how.

\section{What Happened}

\section{The Crimes}

Khmer Rouge leaders Nuon Chea, leng Sary and Khieu Samphan have been charged with both crimes against humanity ${ }^{49}$ and war crimes. ${ }^{50}$ Some interviewees believe that forensic science could play a valuable role in proving certain elements of the crimes committed. As one interviewee said,

[f]orensic scientists will help establish a nationwide pattern of systematic mass murder of 'class enemies' of the Khmer Rouge regime, as well as of certain ethnic and religious groups, such as the Muslim Cham, Buddhist monks, Christians and the Vietnamese minority. ${ }^{51}$

An examination of human remains, as noted above, could establish cause of death and signs of torture, and may reveal artifacts that help prove the religious beliefs of the victims. Investigators could concentrate on exhuming a few sites of key strategic importance to support claims that particular ethnic or religious groups were targeted and killed through large-scale executions, starvation and torture. They could pinpoint a few graves across the country to demonstrate the widespread nature of the killings in Cambodia.

Links to the Perpetrator

\footnotetext{
48 Ibid.

${ }^{49}$ Including murder, extermination, enslavement, deportation, imprisonment, torture, rape, persecution on political, racial and religious grounds and other inhumane acts directed against civilians. See, Law on the Establishment of Extraordinary Chambers in the Courts of Cambodia for the Prosecution of Crimes Committed During the Period of Democratic Kampuchea (27 October 2004), Art. 5.

${ }^{50}$ Article 6 of the law on the establishment of the ECCC provides the Extraordinary Chambers with the power to bring to 'trial all Suspects who committed or ordered the commission of grave breaches of the Geneva Conventions of 12 August 1949.' Ibid.

${ }^{51}$ Email interview, 7 May 2007.
} 
Whilst the base crimes ${ }^{52}$ might be relatively easy to prove, establishing the link between a base crime and a perpetrator will be the real challenge. The defence is unlikely to dispute that the actual killings ever happened but is more likely to argue that defendants have no connection to the crimes. It is predicted that prosecutors will rely predominantly on written evidence to try to prove the chain of command and to establish legal responsibility for the crimes. ${ }^{53}$ Evidence collected by forensic scientists could be one indirect way for the co-investigating judges to establish whether there was a systematic pattern of killings that can be linked to orders given by the defendants. This is not essential, as shown in Rwanda, where thousands of eyewitnesses confirmed the massacres and the International Criminal Tribunal for Rwanda (ICTR) conducted few forensic exhumations. The contexts are significantly different, however. In Rwanda, the ad hoc tribunal was created in November 1994 because of continuing violations of international humanitarian law. Cambodia has been waiting for three decades for trials to take place. If the prosecution relies on Cambodian eyewitnesses, this will mean retrieving painful and possibly inaccurate memories from 30 years ago.

\section{The Individual Witness}

Much mass grave evidence from the Khmer Rouge era has been lost or destroyed as crime scenes have been altered and witnesses' memories may have faded. Forensic science can produce important evidence to corroborate the testimony of survivors and to help compare eyewitness accounts with physical evidence emerging from the graves: numbers of bodies, cause of death, time of death (once decaying processes under Cambodian conditions are better understood) and, if possible, identification. The telling

\footnotetext{
52 'Base crime' is a term frequently used in international criminal law for crimes such as murder, torture or assault committed at the 'bottom' of the command chain. Whilst the perpetrators of the actual killings are not on trial, the crimes they perpetrated (e.g., the base crimes) are important to establish the magnitude of the crimes and who is ultimately responsible for the atrocities.

53 Julia Fromholz 'Proving Khmer Rouge Abuses: Uses and Limitations of the Available Evidence,' in The Khmer Rouge Tribunal, ed. John D. Ciorciari (Phnom Penh, Documentation Center of Cambodia, 2006).
} 
of eye witnesses' stories of killings in court together with presentation of positive identification of the killed victims and the ways they died can provide a powerful corrobortated example of the base crimes.

Forensic science also can help with witness selection. As one interviewee pointed out, 'for the purpose of the trial, you actually want the person who was there and actually saw what happened. ${ }^{54}$ Given the passage of time, it is likely that some witnesses will suffer from memory loss or alteration by adding to their own painful memories details they heard from fellow sufferers, which poses challenges for the investigation. ${ }^{55}$ Furthermore, studies on eyewitness testimony have found that 'recall of details from a violent incident was significantly worse than recall of a nonviolent incident, ${ }^{56}$ which potentially affects accuracy and completeness. Statistics from a 2003 epidemiological study with 610 Cambodians show a high percentage of traumatisation, as described in the 2003-2005 report of the Victims of Torture Project. Eighty-one percent of the Cambodians in the study have experienced violence, with 28.4 percent suffering from post-traumatic stress disorder, 11.5 percent from mood disorder and 40 percent from anxiety disorder. ${ }^{57}$ In his book, The Witnesses, Eric Stover refers to a study on political activists that shows ' 36 percent of those who had been tortured reported an inability to recall an important aspect of the trauma, whereas only 2 percent of those who had not been tortured reported this symptom. ${ }^{58}$ The issue of witness reliability thus could be tested and resolved through forensic science.

\footnotetext{
54 Telephone interview, 4 June 2007.

${ }^{55}$ Neuroscientist Daniel Schacter explains that human memory is susceptible to omitting memories (transience, absentmindedness and blocking) or to remembering things wrongly (misattribution, suggestibility, bias and persistence). Daniel L. Schacter, The Seven Sins of Memory: How the Mind Forgets and Remembers (Boston: Houghton Mifflin Company, 2001).

${ }^{56}$ Brian R. Clifford and Jane Scott, 'Individual and Situational Factors in Eyewitness Testimony,' Journal of Applied Psychology 63(3) (1978): 356.

${ }^{57}$ Documentation Center of Cambodia, 'Victims of Torture (VOT) Project: Helping the Victims of the Khmer Rouge, Final Report,' October 2003 through September 2005 (Cambodia, 2005). http://www.dccam.org/Projects/VOT/Fianl_Report_2005.pdf.

${ }^{58}$ Eric Stover, The Witnesses: War Crimes and the Promise of Justice in The Hague, ed. Bert B. Lockwood (Philadelphia: University of Pennsylvania Press, 2005), 9.
} 


\section{The Numbers}

It is commonly believed that around 20 to 25 percent of the Cambodian population died during the Khmer Rouge era. This led one interviewee to contemplate that the prosecution will 'use science to satisfy that theory, rather than starting from scratch using science to decide how many people actually died. ${ }^{59}$ Indeed the prosecution and coinvestigating judges are unlikely to use forensic science to produce an accurate figure of its own, not least because the original crime scenes have been disturbed. They might, however, attempt to verify death toll estimates to avoid moderation of the deaths attributed to the Khmer Rouge by ascribing culpability to US carpet-bombing prior to 1975, the invasion by Vietnam and the civil war. ${ }^{60}$ Thus, the use of carefully selected exhumations that verify DC-Cam's mapping projections and establish cause and time of death in order to confirm that the victims were from the Khmer Rouge era would put an end to suggestions regarding overestimates of the death toll.

\section{Undertaking Exhumations}

Given that DC-Cam has identified undisturbed graves and conducted preliminary site assessment work, select exhumations should be possible with the right investigative team $^{61}$ and budget. If trials are to start in 2008 , however, time is running out and a

\footnotetext{
${ }^{59}$ Personal interview, 24 April 2007, Phnom Penh, Cambodia.

60 During the Milošević trial, statistician Patrick Ball gave evidence on killings in Kosovo based on a report that contained a statistical analysis of interview records, documents and exhumation reports. The findings showed that killings (and refugee flow) occurred in a regular pattern throughout March-June 1999 and that 10,356 Kosovar Albanians were killed. See, Patrick Ball, Wendy Belts, Fritz Scheuren, Jana Dudukovich and Jana Asher, 'Killings and Refugee Flow in Kosovo March-June 1999: A Report to the International Criminal Tribunal for the Former Yugoslavia' (Washington: American Association for the Advancement of Science, 2002). A similar approach might be feasible in Cambodia.

${ }^{61}$ Raymond McGrath describes what a team investigating war crimes and crimes against humanity should look like as follows: 'The team should consist of a multidisciplinary group of professionals. A team commander who is either a senior investigator or military person should be supported by a criminal lawyer well versed in international humanitarian law $(\mathrm{IHL})$, as well as experts in the scientific disciplines required (pathologists, forensic archaeologists, forensic odontologists, etc.). The team should include a logistician to make all arrangements for travel, equipment, communications, local transport, fuel, and accommodations. Most fundamental are field investigators to help process crimes scenes, interview witnesses and suspects,
} 
request for evidence could be rejected by the Trial Chamber if it is 'impossible to obtain within a reasonable time. ${ }^{62}$ Forensic capacity within Cambodia is limited, ${ }^{63}$ and, according to one interviewee, any team would have to include international experts to carry out the exhumations, as well as to 'introduce this important work to Cambodia. Not just for the tribunal but also for the future as a way to fight crimes in society. ${ }^{64}$

The ECCC's internal rules provide guidance on the employment and use of experts who, on appointment,

shall take an oath with his or her religion or belief to assist the CoInvestigating Judge or the Chambers honestly, confidentially and to the best of his or her ability.'

The task to be completed by the expert has to be clearly defined in scope and aim from the outset, and relevant evidence must be made available to the experts to help them fulfill their duties properly. A comprehensive report outlining all activities is to be submitted to the co-investigating judges or the Chambers on completion of the mission. ${ }^{66}$

\section{Beyond the Trial}

Forensic science exhumations provide information not only for legal purposes but also for humanitarian ones. As forensic anthropologist William Haglund points out, exhumations assist in establishing accountability; raise awareness; help identify victims; create an account that is immune to revisionism; and lend dignity to victims, their

and develop leads. It should also include analysts to interpret documents, witness statements, and other intelligence; as well as interpreters fluent in the languages of the theatre of operations. Finally, the team should include technical support to maintain equipment and software.' McGrath, supra n 38 at 896.

62 Extraordinary Chambers in the Courts of Cambodia, supra n 43 at Rule 87(b).

63 One respondent believes that there are a few Cambodian forensic experts who were trained in Russia and Vietnam.

${ }^{64}$ Personal interview, 27 April 2007, Bangkok, Thailand.

${ }^{65}$ Extraordinary Chambers in the Courts of Cambodia, supra n 43 at Rule 31(2).

66 Ibid. 
families and human life in general. ${ }^{67}$ Indeed, some of these purposes go beyond the trial and are directed at meeting the needs of the local population.

The awareness of what forensic science can achieve is still underdeveloped in Cambodia, as demonstrated by the failure of DC-Cam's forensic exhibition initiative. According to interviewees, people are gradually starting to understand and accept that forensic examinations of victims, such as autopsies, can provide valuable evidence and assist in the administration of justice. The Cambodian people are culturally and religiously sensitive about treatment of the deceased, believing that the spirits of those who die unnatural deaths cannot rest and therefore may cause misfortune amongst the living. ${ }^{68}$ That said, given their history, Cambodians have become accustomed to seeing human remains on display, whether for commemorative, educational or political purposes. The preservation of human bones as evidence has the explicit support of Cambodian Prime Minister Hun Sen, who in 2001 urged local authorities

to cooperate with expert institutions to examine, restore and maintain all existing memorials, and to examine and research other remaining grave sites, so that all such places may be transformed into memorials. ${ }^{69}$

However, exhumation of dead bodies is, as one respondent explained, 'not acceptable for the Cambodian people. ${ }^{70}$

It is pressing that the remains be preserved from further decay, looting ${ }^{71}$ and disturbance by animals, for legal as well as historical and educational reasons. A gap in perception exists between those immediately affected by the Khmer Rouge terror and

\footnotetext{
${ }^{67}$ William D. Haglund, 'Recent Mass Graves: An Introduction,' in Advances in Forensic Taphonomy: Method, Theory and Archaeological Perspectives, ed. William D. Haglund and Marcella H. Sorg (Boca Raton, London: CRC Press, 2002).

${ }^{68}$ Cougill, supra $\mathrm{n} 29$.

69 Documentation Center of Cambodia, 'Government Circular on the Preservation of Victim Memorial,' 2001, http://www.dccam.org/Projects/Maps/Victim_Memorials.htm.

70 Personal interview, 25 April 2007, Phnom Penh, Cambodia.

${ }^{71}$ As reported by the International Herald Tribune from Sre Liev village in May 2007, undisturbed graves can become subject to looting by impoverished locals. In the process, bones get piled up in the open. 'After the assault on the burial ground,' Seth Mydans recounts, 'this village seemed filled with remorse and dread.' Seth Mydans, 'Villagers Find and Loot Cambodian Killing Field,' International Herald Tribune, May 15, 2007.
} 
the younger generations. Today's children, as one interviewee observed, assume that unburied or undisplayed human remains belong to bad people who do not deserve better treatment. Physical evidence that records the trauma suffered by victims would help to rectify that perception and provide some dignity to those anonymous dead.

Contrary to the government's policy of displaying human remains, former King Norodom Sihanouk favours mass cremation of Khmer Rouge victims, a proposal that might be realized once the ECCC has finished its work. Cremation of the remains, which Cambodians believe would liberate the souls of the dead for reincarnation, is difficult because individual human remains belong to the families of the deceased. In order to return remains to victims' families, identification would be necessary. This places Cambodians in an impossible situation, as identification would require that all recovered remains be examined. Even if it were realistic to attempt to identify all the remains through DNA analysis, which would require extensive interviewing and gathering of antemortem data, it is questionable whether the population would want all human remains to be examined and each grave to be exhumed. Identification efforts would, however, provide an opportunity to educate Cambodians and demonstrate the significance of individual human dignity.

Ultimately, the decision of what to do with the human remains, both on display and in graves, lies with the Cambodian people and their government. Cambodians' views on this matter must be ascertained prior to any decision being made regarding cremations, exhumations, examinations or displays, and this would provide an interesting direction for further research. In any event, before examinations and exhumations outside a legal mandate are conducted, it should be clear what is to happen to the remains. 


\section{Forensic Science, 30 Years After the Event?}

In the Cambodian context, forensic science would bring an important dimension to the documentation of past atrocities. It would complement the predominantly social science research conducted to date. Through its methods of logging and recording, it would provide transparent, factual accounts, including cause of death, signs of torture or starvation, sex, age, time of death and potentially identification. As discussed above, a number of reasons exist for conducting carefully selected forensic science exhumations, if only to ensure that some 'crime scenes' are recorded whilst they remain intact.

Moreover, one dimension of the ECCC's purpose is to serve as a model for reforming Cambodia's legal system. ${ }^{72}$ Given one interviewee's suspicion that there is not 'a single Cambodian lawyer who has ever used a scientist to try and prosecute a case, ${ }^{73}$ introducing forensic science to judicial proceedings provides an excellent opportunity to build local capacity in this area. This, in turn, would help empower Cambodians to have an educated debate on the future of the country's human remains, weighing the use of exhumation and preservation with cultural, religious, historical and political arguments.

The ECCC is expected to make an important contribution to Cambodian history and collective memory through its judgments and legal documents. Collecting all available evidence, in particular physical evidence, using scientific methods, will help provide as comprehensive and impartial an account of events as possible. In order to bring useful forensic science evidence to the Extraordinary Chambers, undisturbed graves and easy access to the graves are essential. The site selection phase of the DCCam forensic project established that finding undisturbed graves will be more difficult

\footnotetext{
${ }^{72}$ At a symposium in 2003, members of Cambodian civil society expressed the hope that the trials would: create justice for victims by holding perpetrators accountable; provide an explanation for why the Khmer Rouge leaders killed their own people; function as a deterrent for leaders throughout the world; catalyze the healing of Cambodian society for the psychological trauma inflicted during the Khmer Rouge era; and serve as a model in reforming Cambodia's legal system. Kelli Muddell, 'Transitional Justice in Cambodia: Challenges and Opportunities. Symposium Report' (New York: The Asia Society, Human Rights Watch, the International Center for Transitional Justice, 2003).

${ }^{73}$ Personal interview, 24 April 2007, Phnom Penh, Cambodia.
} 
than expected. The time for forensic scientists to gain firsthand information from witnesses is running out, as is time for the ECCC to investigate crimes before the trials start. Sadly, it increasingly seems as if an opportunity to gather evidence that is distinct from what is already available to the ECCC will be missed. 